\title{
Geothermal hot water potential at Parangwedang, Parangtritis, Bantul, Yogyakarta as main support of Geotourism
}

\author{
KRT. Nur Suhascaryo ${ }^{1, *}$, Hadi Purnomo ${ }^{1}$, and Jatmika Setiawan ${ }^{1}$ \\ ${ }^{1}$ Faculty of Mineral Technology, UPN Veteran Yogyakarta, 55281 Yogyakarta, Indonesia
}

\begin{abstract}
The paper aims to determine the condition of Parangwedang as hot spring source in Parangtritis, Bantul, Yogyakarta and provide a guidance to develop Parangwedang as one of tourism destinations by controlling geological factor. The study is limited to examining the physical condition in the form of color, turbidity, odor, temperature and chemical condition $(\mathrm{pH})$, compositions of calcium $(\mathrm{Ca})$, sodium $(\mathrm{Na})$, silica $\left(\mathrm{SiO}_{2}\right)$, magnesium $(\mathrm{Mg})$, bicarbonate $\left(\mathrm{HCO}_{3}\right)$, sulfate $\left(\mathrm{SO}_{4}\right)$ and chloride $(\mathrm{Cl})$ and water source debits of Parangwedang hot springs as part of geohydrology research. The methodology used in the paper is divided into three steps. Firstly, the methodology was based on orientation and survey location. Then, it examined mapping the hot water temperature distribution. Lastly, it was implementing laboratory analysis of rocks and water. As a result, the paper portrays that there are potential water of hot of spring which meets the standards as clean water and the heat capacity can be utilized to support as geological tourism at Parangwedang, Bantul, Yogyakarta, Indonesia.
\end{abstract}

\section{Introduction}

Natural resources are being popular among tourism industry, for example in Bantul, Yogyakarta, which offers several beaches such as Parangtritis, Samas, Baron, Kukup, Krakal and Glagah Beach. Those places are well known for their eye catching view of the nature that portrayed in the area. Geothermal phenomenon is one example of natural resources that has attractiveness in tourism industry. This condition is commonly known as geotourism.

Geotourism as a natural attraction is being promoted alongside with the beautiful landscape of the beach. It uses geothermal fluid consisted of water, steam, and fumaroles that are carried out of the surface in the tourism activities. The fluid that appears on the surface is commonly used for bathing, swimming-pools of hot water, and medical therapy. The development of geotourism can be an added value that increases local revenue and the welfare of the population.

Geotourism is implemented in Parangtritis area in Bantul, Yogyakarta. Parangtritis is located in $\pm 30 \mathrm{~km}$ in south of central of Yogyakarta. The location is a coastal tourist spot of Indian Ocean. Based on the geographical position, Parangtritis is located in front of the path of active subduction zone of southern Java, namely the collision between the Indian Ocean and Australian plate under the Eurasian Plate. It leads to tertiary volcanic pathways that can lead to the emergence.

In addition, there is a hot water spring area in Parangtritis area, namely Parangwedang. The average fluid temperature in Parangwedang is at an average $<50$
$\mathrm{C}$ and it can be used for baths and hot tubs. Reviewing from its utilization, hot fluid distributions in Parangwedang are not fully utilized. It seems that Parangwedang needs huge exposure of its potential attraction in terms of geotourism.

Nevertheless, it is not an easy task to promote Parangwedang with its geotourism concept as tourism attraction because up to recent condition it has not been popular yet among tourist visitors although local government of Bantul has been managed tourism in Parangtritis area pretty well. As an illustration, Depok beach which offers a common attraction such as culinary is more popular than Parangwedang which offers limited attraction such as hot water spring area. Its visitors that come intensely can be counted few people. Their purposes are experiencing bathing, relying on tourist overflow from Parangtritis, doing a skin disease treatment by soaking in hot water which contains sulfur, until coming for spiritual purposes. This circumstances occurred in Parangwedang were attracted the researchers to conduct this research.

In relevance, the research aims to portray geotourism condition and opportunity that can be enhanced in Parangwedang and suggest a guidance on how to develop Parangwedang for tourism attraction, especially by controlling the geological factor. This geological research focuses on knowing the physical condition in the form of color, turbidity, odor, temperature and chemical condition $(\mathrm{pH})$, compositions of calcium $(\mathrm{Ca})$, sodium $(\mathrm{Na})$, silica $\left(\mathrm{SiO}_{2}\right)$, magnesium $(\mathrm{Mg})$, bicarbonate $\left(\mathrm{HCO}_{3}\right)$, sulfate $\left(\mathrm{SO}_{4}\right)$ and chloride $(\mathrm{Cl})$ and water source debits of Parangwedang hot springs as part

*Corresponding author: suhascaryo@yahoo.com 
of geohydrology research. This research refers to science and technology development.

\section{Geological review}

Parangtritis is located on the topographic map sheets 47/XLIII-c, sheet 47/XLII-c and sheet 47 / XLII-b, with a map 1:25,000 scale. Administratively it is located between $8^{\circ}$ South Latitude and $110^{\circ}$ East Longitude. The study area is in the Mancingan, Kretek District, Bantul (see fig.1).

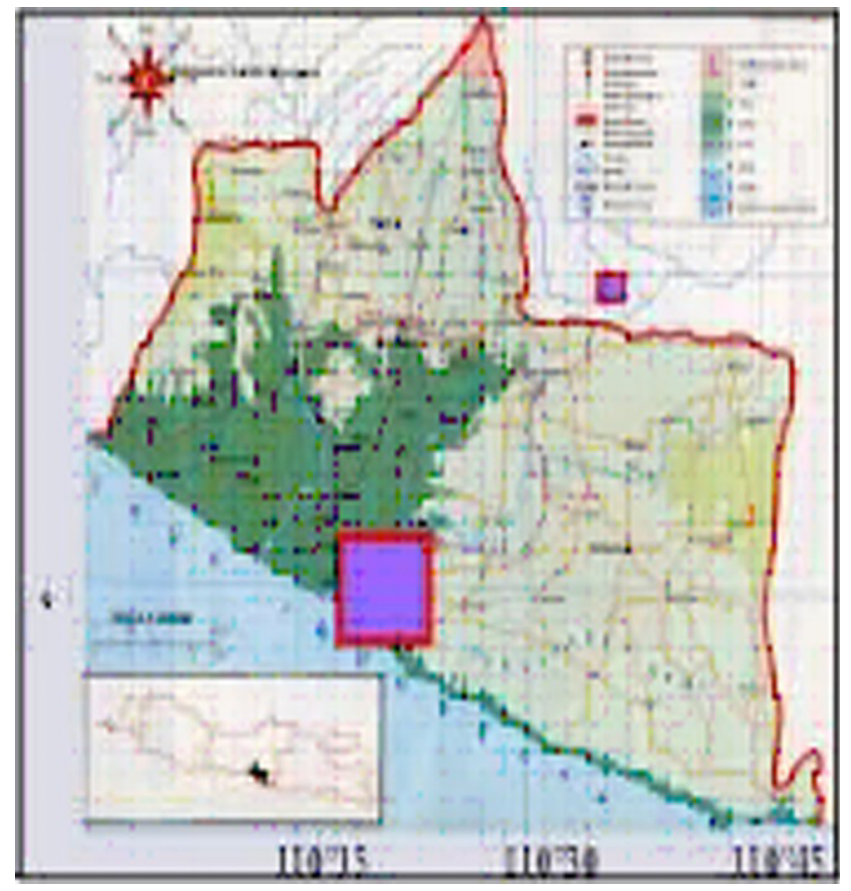

Fig.1. Parangtiritis Topographic Map

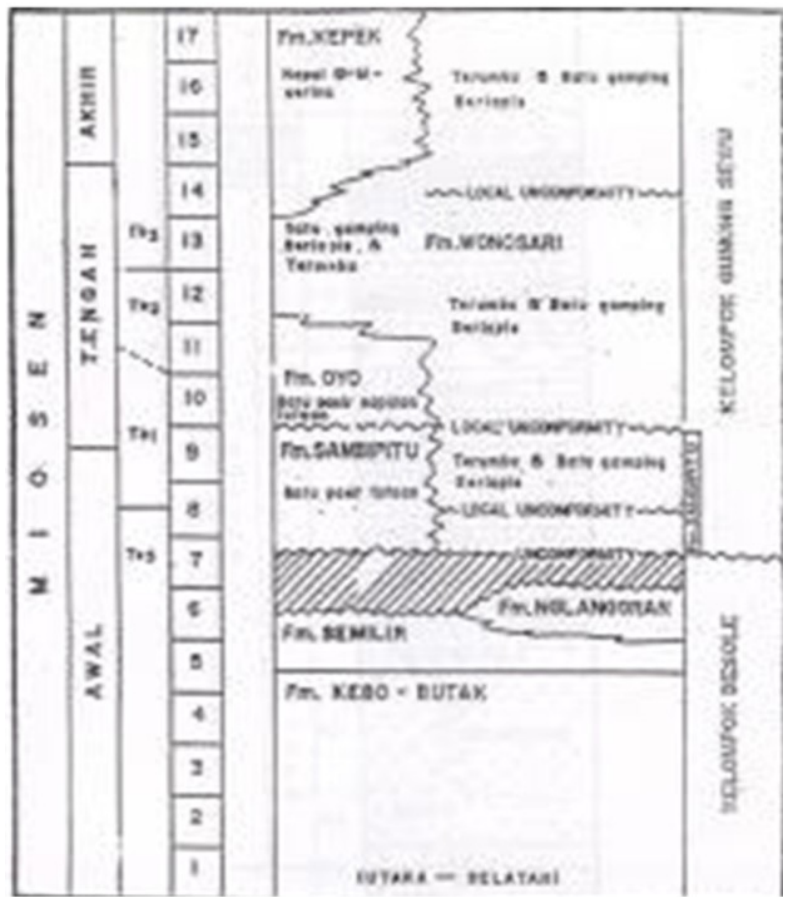

Fig.2. Stratigraphy Southern Mountains (Suyoto, 1992)
There are several places surrounded Parangtritis area. In the north is bounded by the Opak river and Oyo river, the southern part is bounded by the Indian Ocean, the eastern part is bounded by Sewu Karst mountains and the western part is bounded by Opak river downstream. Geologically, Parangtritis is located in Central Java Province South Mountains Zone and the coastal alluvial plain zone (Bemmelen, 1949). According to Rahardjo, et al (1977) and Surono, et al (1992), the oldest rocks in the South Mountains in the form of Pre-Tertiary metamorphic rocks were exposed in the Jiwo Hills, Bayat, Klaten regency, Central Java. In the western part of South Mountains, above metamorphic rocks were deposited sequenced Gamping-Wungkal Formation, Kebo-Butak, Semilir, Nglanggran, Sambipitu, Oyo, Wonosari, Kepek and alluvium sediments. According to Suyoto (1992), he suggested the structure of the stratigraphy in the Southern Alps as seen in fig. 2.

\section{Methodology details}

There were three stages implemented in conducting the research. They are:

Stage 1, literature and the provision of basic map (preparation) was used to obtain information related to the study. Secondary data were needed in the form of a topographical map, a map in such a world, analysis and interpretation, geological maps regional concerned areas, the study of reports/articles/papers in good geological condition, geochemistry, hydrothermal research of previous investigators, and information from the Internet.

Stage 2, phase study of area or field observation was direct research activities in the field, by data recording of geological phenomena, landscapes and environment observation, and also water sampling at Parangwedang. The findings were analyzed in the laboratory.

Stage 3, the analysis in the laboratory was testing to determine the geological and environmental aspects which include the analysis of physical characteristic of hot springs include color, turbidity, odor, and temperature. Meanwhile, hot springs chemical analysis was by testing $\mathrm{pH}$, hardness, and nitrite. Then, inundated condition analysis was carried out in two places, namely in the field and Industrial Engineering Laboratory of UPN Veteran Yogyakarta.

\section{Result and discussion}

Morphology research areas included in Southern Mountains zone in Central Java and Yogyakarta were found undergoing a process of the sinking. It was covered by alluvial sediments in the form of broad coastal plain, from Parangtristis to Kebumen and appeared in the Karangbolong Hills and Nusakambangan Island (Bemmelen, 1970). Then, the top of South Mountain was largely composed of Miocene limestone, which had undergone a process of dissolution form karst topography, such as reefs hills, limestone caves in which rivers flow underground. Meanwhile, there are three subzones in the Southern Mountain, namely Northern 
subzone or better known as Complex Batur-Grand (Baturagung range), Midsection subzone or better known Wonosari and Southern subzone or better known by the name of Thousand Mountains (Sewu Mountains).

Sewu Mountains has elevation between 0-400 meters above sea level, which is composed of material that is readily soluble limestone. Sewu Mountains are divided into three zones, the North, Central and South region. In physiographic, Parangtritis and surrounding areas that lie in the South Central Java Plato zones which are formed by karst mountains are bordered by Baturagung Strip, and beside around Opak river estuary is a coastal alluvial plain (Pennekoek, 1949).

Parangtritis area and surrounding area stratigraphy are structured by Tertiary rocks composed by clastic volcanic sedimentary rocks, volcanic rocks and clastic carbonate sedimentary, as well as surface-old sediment quaternary (Idral et al, 2008). Clastic volcanic rocks are structured by clastic volcanic rock units which are in Semilir Formation. It consists of an ash-sized interlude tuff to lapilli and Miocene. These rock units are waterproof and found has become bedrock in the research area. In addition, volcanic rocks which are constituent rocks are composed by andesite breccia and andesite lava were found included in Nglanggran formation. This andesite breccia extended in the north and west of research areas with the general slope elevation to the south-southeast. Furthermore, igneous andesite rocks were found in Grogol Village and Bibis Village in outcrop conditions which were still fresh with a stocky structure of shear zones. Andesite is an igneous rock that is contained in the surface or near surface which typically lava forms, dike and sill. Next finding is located in Parangkusumo area nearby Parangwedang. There was found common black basalt lava gray-green with lava flows and fractured structure with parallel pattern or a hefty plate.

Clastic sedimentary carbonate rocks are constituent lithologies which consist of limestone reefs and kalkarenit included in Wonosari Formation aged between Middle Miocene and Under Pleistocene (Wartono-Rahardjo et al, 1977). The position of the rock layers is generally between $\mathrm{N} 50^{\circ} \mathrm{E}-\mathrm{N} 70^{\circ} \mathrm{E}$ with $4^{\mathrm{O}}-28^{\circ}$ elevation to the south. Clastic sedimentary carbonate deployment was found located on the western and eastern of research areas with the karst hills appearance.

Sediment surface is deposition of alluvium which consists of clay to gravel shuffling results of weathering and leaching surrounding rock and shore sediment that composed of fine-sized till coarse-sized sand, sandbanks forming crescent type along the Parangtritis coast until Depok Beach. According to Idral, et al (2008), the pattern of the geological structure in Parangtritis region is mostly structured by the symptoms associated with tectonic that had ever happened in the Java Trench and the formation of mountain systems in the south of Java. Structures in Parangtritis area is normal fault (Bantul, Bambang Lipuro and Mudal), Horizontal fault (Parangkusumo, Soka Nambangan and Siluk) and stocky-built Fault, with the orientation of the fault SENW and NE-SW. Parangkusumo faults trending $\mathrm{N} 300^{\circ} \mathrm{W}$ sub ducting $80^{\circ}$ to the southwest, is an important fault that controls the appearance of Parangwedang hot water spring.

Hydro geological of Parangtritis area defined by the climate and geology or geomorphology of the area and divided into 3 units of hydrogeology; (1) The area traversed by Oyo river and Opak river fluvial sediment with porous material, (2) Regional alluvial beaches and dune sand, where most rain seep into the porous soil into groundwater and (3) The topography area above the Karst Sewu Hills with specific appearance, such as developing its dissolution cavities, the water flow that suddenly disappear and underground drainage system.

In addition to the hydro-geological characteristics above, the hot springs in Parangwedang has founded which is hot spring fissure due to the influence from Parangkusumo fault and the groundwater heated by a heat source (magma) or associated with symptoms of post-volcanic. The hot rocks are thought to result igneous intrusions in the surrounding LYSIS areas. Based on observations in the field there are three hot springs that emerge with gas bubbles and accommodated in storage ponds of hot water which has an area of $8 \times 9$ meters, the color of the water in the ponds is green, due to achieved by high amount of algae (fig. 3).

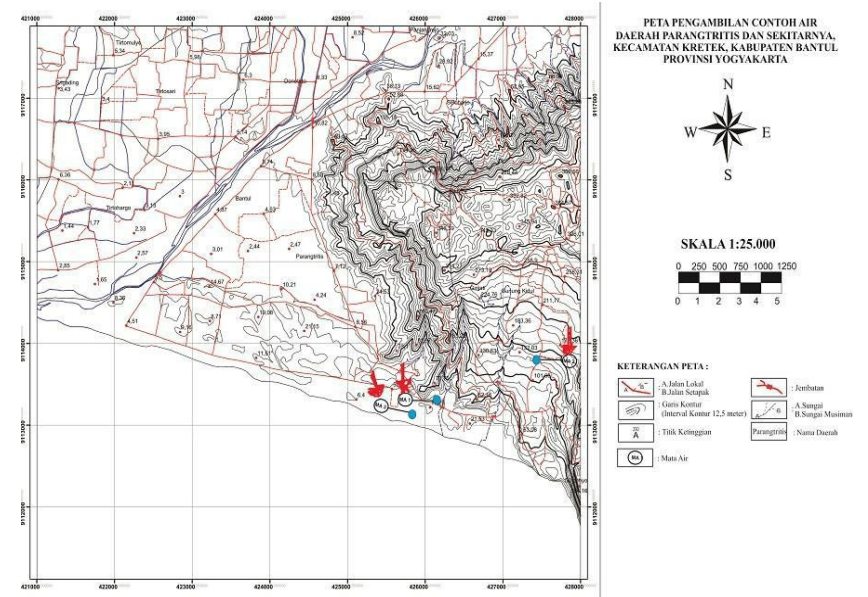

Fig.3. Sampling Hot Water Spring in Parangwedang

Based on physical analysis, chemical and limited microbiological performed on water samples analysis, it can be argued on the analysis of physical results, chemical and micro-biological limited to Parangwedang hot spring (sample is checked in the location the temperature is $44^{\circ} \mathrm{C}, \mathrm{pH}$ is $7.8, \mathrm{CaCO}_{3}$ is $1,795 \mathrm{mg} / 1$ hardness, sample is checked in the laboratory temperature is $29^{\circ} \mathrm{C}, \mathrm{pH} 7.5, \mathrm{CaCO}_{3}$ is $3,385 \mathrm{mg} / 1$ hardness which has an amount of dissolved substances (TDS) about $1.283 \mathrm{mg} / \mathrm{l}$, Color $2 \mathrm{PtCo}, 0.002 \mathrm{mg} / 1$ nitrite, $8 \mathrm{MPN} / 100 \mathrm{ml}$ MPN Coliform and $5 \mathrm{MPN} / 100$ grams fecal coli MPN). See at table 1.

From the table, it portrays several findings, such as the concentration of a MAP dissolved chemical compound 1 and 3 in Parangwedang are significant in $\mathrm{mg} / \mathrm{L}$ units is among $\mathrm{Cl}=7291.06 ; \mathrm{Na}=2470.59 ; \mathrm{Ca}=$ 2450.98; $\mathrm{SiO}_{2}=62.25 ; \mathrm{Mg}=11.62 ; \mathrm{NH}_{4}=5.1 ; \mathrm{B}=$ $7.71, \mathrm{~F}=2$, while $\mathrm{Al}, \mathrm{Fe}$ and $\mathrm{As}$ are undetected. Then MAP Parangwedang 2, the concentration of dissolved 
Table 1. Result and Sample Analysis

\begin{tabular}{|c|c|c|c|c|c|c|c|}
\hline \multicolumn{8}{|c|}{ Samples Analyzed in The field } \\
\hline No. & \multicolumn{3}{|c|}{$\begin{array}{l}\text { Results of the } \\
\text { Analysis }\end{array}$} & \multicolumn{4}{|c|}{ Water Quality Standards } \\
\hline & 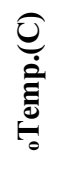 & $\frac{\pi}{2}$ & & & & $\frac{\pi}{2}$ & 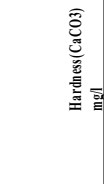 \\
\hline 1. & 40 & 7.6 & 1,790 & 3 & & $\overline{.5-8.5}$ & 500 \\
\hline 2. & 30 & 7.5 & 1,790 & 3 & & $.5-8.5$ & 500 \\
\hline 3. & 44 & 7.8 & 1,795 & 3 & & $, 5-8,5$ & 500 \\
\hline \multicolumn{8}{|c|}{ Samples Analyzed in the Laboratory } \\
\hline & \multicolumn{3}{|c|}{ Parameter } & \multicolumn{2}{|c|}{$\begin{array}{c}\text { Results of the } \\
\text { Analysis }\end{array}$} & \multicolumn{2}{|c|}{$\begin{array}{c}\text { Quality } \\
\text { Standards }\end{array}$} \\
\hline 1 & \multicolumn{3}{|c|}{ Temperature } & \multicolumn{2}{|c|}{$29^{\circ} \mathrm{C}$} & \multicolumn{2}{|c|}{$3^{\circ} \mathrm{C}$} \\
\hline 2 & \multicolumn{3}{|c|}{$\mathrm{pH}$} & \multicolumn{2}{|l|}{7.5} & \multicolumn{2}{|c|}{$6.5-8.5$} \\
\hline 3 & \multicolumn{3}{|c|}{$\begin{array}{c}\text { Hardness } \\
\left(\mathrm{CaCO}_{3}\right)\end{array}$} & \multicolumn{2}{|l|}{$3,385 \mathrm{mg} / 1$} & \multicolumn{2}{|c|}{$500 \mathrm{mg} / 1$} \\
\hline 4 & \multicolumn{3}{|c|}{$\begin{array}{c}\text { Total of } \\
\text { Dissolved } \\
\text { Substances } \\
\text { (TDS) }\end{array}$} & $1,283 \mathrm{mg} / \mathrm{l}$ & & \multicolumn{2}{|c|}{$500 \mathrm{mg} / 1$} \\
\hline 5 & \multicolumn{3}{|c|}{ Color } & \multicolumn{2}{|l|}{$2 \mathrm{PtCo}$} & \multicolumn{2}{|c|}{$15 \mathrm{PtCo}$} \\
\hline 6 & \multicolumn{3}{|c|}{ Nitrite } & \multicolumn{2}{|c|}{$0.003 \mathrm{mg} / 1$} & \multicolumn{2}{|c|}{$1.0 \mathrm{mg} / 1$} \\
\hline 7 & \multicolumn{3}{|c|}{$\begin{array}{c}\text { MPN } \\
\text { Coliform }\end{array}$} & $8 \mathrm{MPN} / 100 \mathrm{ml}$ & & \multicolumn{2}{|c|}{$50 \mathrm{MPN} / 100 \mathrm{ml}$} \\
\hline 8 & \multicolumn{3}{|c|}{$\begin{array}{c}\text { MPN } \\
\text { Coli Tinja }\end{array}$} & \multicolumn{2}{|l|}{$\begin{array}{c}5 \mathrm{MPN} / 100 \\
\text { gram }\end{array}$} & \multicolumn{2}{|c|}{$\begin{array}{c}10 \mathrm{MPN} / 100 \\
\text { gram }\end{array}$} \\
\hline
\end{tabular}

and $\mathrm{Fe}=0.04$, while $\mathrm{Al}$ and As are undetected. From the limited physical, it refers that chemical and microbiological analysis to the findings above which are the hardness of $\mathrm{CaCO}_{3}$ at $3,385 \mathrm{mg} / \mathrm{l}$ has been exceeded from quality standards which is formed by Ministry of Health Decree No. 416/Menkes/Per/IX/1990 which is supposed to be equal to $500 \mathrm{mg} / \mathrm{l}$.

In addition, the result of the dissolved substance amount (TDS) of $1,283 \mathrm{mg} / \mathrm{l}$ is quite high, and has exceeded the quality standard by The Minister of Health No. 416/Menkes/Per/IX/1990 that has to be equal to 500 $\mathrm{mg} / \mathrm{l}$. Meanwhile in microbiological analysis, researcher found that MPN Coliform and MPN Fecal Coli were under quality standard. Concluding from all above, the data were found that Parangwedang hot spring already met the standards as clean water, so it can be used for hot spring.

The literature review which examines the results of the integrated geological, geochemical and geophysical investigation for geothermal Parangtritis regions (Idral et al, 2008), indicates that there is a potential for geothermal utilization in Parangwedang because it has low enthalpy with the temperature (T) below the surface which is smaller than $125^{\circ} \mathrm{C}$. This condition presents that Parangwedang is safely can be used for a hot water bath.

Moreover, the analysis of the triangle diagram Cl$\mathrm{SO}_{4}-\mathrm{HCO}_{3}$ based on literature review about the type of hot water which mentioned the type of chloride or $\mathrm{Cl}$ (Nicholson, 1993), is in line with the presence of chloride found which is generally indicated by the high permeability reservoir zone (breccia fault on the pipe eruption). The phenomenon emerged by the condition of
Parangwedang hot spring which is formed by Parangkusumo across fault.

The further discussion in this research is that the reserves quantity of groundwater in the research area is large enough to warrant the formation of a natural steam and hot water. Perhaps, it is occurred because of meteoric water which can infiltrate through the karst topography of the area as well as upland areas Oyo river and Peel river, then it is turned form the groundwater reservoir rocks of andesite breccias, and also because of the presence hot springs which has high Chloride inside Parangwedang that can be useful as disinfectant and skin bleaching. Consequently, Parangwedang has high probability to offer hot water spring with good quality in Parangwedang to be used as geotourism.

Nevertheless, current condition of Parangwedang hot spring as mentioned before has to be developed to support the idea of making Parangwedang as profitable geotourism. If the location does not well maintain, the potential means nothing than only natural phenomenon. The researchers suggest that local government collaborated with local people in Bantul to improve its promotion and facility. It can be started from improving the extent of cleanliness, public needs in the area, comfortable access to reach the area, conducting various activities, or even by building a well designed interior and decoration in the location. The government may alliance with several sponsors to support this idea. Researchers believe that Parangwedang can be one of popular geotourism in Bantul and attract huge visitors if it is well developed and maintained. In order to support this idea, the researchers also suggest that further research will also useful to examine deeply in supporting the proof that Parangwedang has the potential as geotourism. The future research may explore in the field of hot springs discharge research, implementation of engineering technology, or economical and management development in this case.

\section{Conclusion}

Below are the conclusions after researchers conducting the research:

First, the rocks in the Parangtritis area are structured by Tertiary rocks which are composed by volcanic clastic sedimentary rocks, volcanic rocks and clastic sedimentary carbonates, as well as surface sediment Map Quaternary aged. Parangwedang appear in alluvium rocks that are controlled by the northwest-southeast Parangkusumo trending fault. The existence of this fault is also supported by magnetic anomalous, gravity, resistivity and head-on.

Second, geothermal expression in Parangtritis area such as hot springs, which appears in Parangwedang 1 and 3, each with a temperature of $40^{\circ} \mathrm{C}$ and $44^{\circ} \mathrm{C}$ with a normal $\mathrm{pH}$. Parangwedang hot spring has chloride type due to contamination with sea water, while it is below the surface temperature and estimated about $115^{\circ} \mathrm{C}$.

Third, the main structure of this area is trending to northwest-southeast which opens towards the south, where is an area of hydrothermal alteration characterized by the presence of mineral chlorite and sericite. Source 
rocks are not exposed on the surface and it is estimated as residual magma rock due to subduction zone in South Java and predicted as heat source in investigation area. Meanwhile, reservoir of geothermal area is estimated to be at 600-700 meter depth.

Last, according to the analysis of geological, the limited physical, chemical and microbiological analysis, Parangwedang in Parangtritis area, has a potential of groundwater as a source of hot water spring and it needs to be overlooked by local government and local people, or even sponsor, while further research in this field is also still available to support the idea such as the fields of hot springs discharge research, implementation of engineering technology, or economical and management development in this case.

\section{Further research}

As mentioned earlier, there are several topics available for further research related to this current research. They are:

a. Hot springs discharge research

b. Implementation of engineering technology research

c. Economical and management development research (DCF, real option, marketing, etc)

\section{References}

1. Anonymous. The Minister of Health Quality Standard Number 416/Menkes/Per/LX/1990. Ministry of Health: Jakarta, Indonesia. (1990)

2. Anonymous. The Southern Mountains Field Test Guidelines. Geological Engineering of UPN Veteran Yogyakarta: Yogyakarta, Indonesia.

3. Chasin, M. Inventory of Appearance of Symptoms Geothermal. Yogyakarta Regional Directorate of Volcanology: Yogyakarta, Indonesia. (1974)

4. Geothermal Regional Integrated Team Adum. Unpublished Report of the Regional Integrated
Research Geothermal Adum. Lembaga District: NTT: NTT, Indonesia. (2002).

5. Idral, A., Suhanto E, Sumardi, E., Kusnadi, D and T. Situmorang. Integrated Research Geology, Geochemistry and Geophysics Geothermal Regional Parangtritis, Subdit Geothermal. ITB Central Library: Bandung, Indonesia. (2008)

6. Kadar, D. Biostratigraphy of Neogene Planktonic Foraminiferal The Area South Central Java, Indonesia. Special Publication No. 5. Geological Research and Development Centre: Bandung, Indonesia. (1986)

7. Komazawa..M.,et al. Gravity Anomalies of the Central Flores Island, Indonesia. page 211 - 223.

Special Publication: Indonesia-Japan Geothermal Expl. Project: Flores Island, Indonesia. (2002)

8. Kusumadinata, K., Alzwar, M. Mapping the spread of geothermal manifestations in Java Island, Directorate of Volcanology. Bandung. (1969).

9. Nicholson, K. Geothermal Fluids: Chemistry and Exploration Technique page 262. Springer-Verlag: Berlin, Germany. (1993)

10. Pannekoek, A.J. Outline of the geomorphology, of Java, Geological Survey. T.A.G.:The Netherlands. (1949).

11. Telford, W.M. et al. Applied Geophysics. Cambridge University Press: Cambridge, United Kingdom. (1982)

12. Thornburry, W.D. Principle of Geomorphology 2nd Edition. Mc Graw Hill: New York, USA. (1969).

13. Van, Bemmelen, R.W. The Geology of Indonesia Vol. 1B. Government Printing Office: The Hague, Netherlands. (1949).

14. Wartono, R., Sukandar, R., and Rosidi, H.M.D. Geological Map Sheet Yogyakarta, Java. Issue 2. P3G: Bandung, Indonesia. (1995).

15. Wohletz, K., Heiken, G. Volcanology and Geothermal Energy. University of California Press: Los Angeles, USA. (1992). 